\title{
Разъединенность в глобальном джихаде: предисловие
}

\section{Манни Крон и Флемминг Сплидсбуэль Хансен}

Датский институт международных исследований, http://www.diis.dk

В то время, когда это специальное издание «Разъединенность в глобальном джихаде» пошло в печать в январе 2017, Исламское государство (ИГ) стоит перед возможным военным поражением на всей своей территории в Северном Ираке и в Сирии. И в то же самое время, оно с гордостью берет на себя ответственность за теракт с грузовиком на Рождественском базаре в Берлине 19 декабря 2016 года и за нападение в ночном клубе Стамбула 1 января 2017 года. Эксперты предупреждают, что по мере распада халифата ИГ, эта организация может переориентировать фокус своей деятельности - через множество своих приверженцев начать совершать еще больше террористических нападений в больших частях остального мира, разумеется, в том числе и на Западе.

Большое внимание, уделяемое западными СМИ ИГ, вытолкнуло Аль-Каиду (АК), до недавнего времени являющуюся объектом большинства контртеррористических теорий и усилий, на задний двор нашего коллективного сознания. АК, используемая в настоящее время в качестве объединяющего бренда для более маленьких группировок, функционирующих под ее именем, однако, все еще активна, и в нескольких местах вошла в кровавый конфликт с ИГ. Возможное военное поражение ИГ в Северном Ираке и Сирии от союза местных и иностранных войск может проложить дорогу к новому утверждению АК на глобальной джихадистской сцене. В нескольких публикациях этого 
специального издания при обсуждении соперничества между ИГ и АК высказывается предположение, что на нескольких театрах военных действий такое развитие событий возможно.

Это специальное издание базируется в основном на работах Датского института международных исследований (ДИМИ), где после появления ИГ более традиционные контртеррористические исследования были дополнены исследованиями по вопросам контр-радикализации. Специальное финансирование разными датскими министерствами позволило ДИМИ создать значительную базу исследований, часть которой сейчас предлагается вниманию читателей Connections. Авторы выражают свою благодарность Редакционному совету Консорциума ПрМ за возможность осуществить это специальное издание.

Копенгаген, 4 января 2017

\section{О приглашенных редакторах}

Доктор философии Манни Крон является старшим научным сотрудником Датского института международных исследований. Предметом ее текущих исследований является терроризм и контртерроризм в Европе, Северной Африке и Сахели. В число ее последних публикаций входят: "Radicalization revisited," International Affairs 92:3 (2016) и "French interventionism in the post-American MENA-region: filling a void?," в Between Regional Autonomy and Intervention: New Conflict Dynamics in the Middle East and North Africa (DIIS, 2017).

Доктор Флемминг Сплидсбуэль Хансен является старшим научным сотрудником и координатором отдела по исследованиям международной безопасности ДИМИ. До поступления на работу в ДИМИ он занимал разные должности в представительстве ОБСЕ в Таджикистане, в нескольких университетах и в вооруженных силах Дании. В круг его исследовательских интересов входят политика в отношении российской идентичности, российские дезинформационные кампании и интеграция на постсоветском пространстве. Флемминг Сплидбуэль Хансен является приглашенным редактором этого издания, и с ним можно связаться по электронному адресу fsha@diis.dk. 